University) and Joel Rogers (Sociology and Law, University of Wisconsin). In "Homework Regulation and the Devolution of the Postwar Labor Standards Regime: Beyond Dichotomy," Boris explored the regulatory dichotomy between home and workplace created by the prohibitions on industrial homework in the Fair Labor Standards Act. She showed how this regulatory and ideological dichotomy rendered the FLSA unable to contain the rightist assault on labor standards, which became particularly apparent during the 1980s. Rogers's paper, "The LaborManagement Relations Act: The Legal Constraints on Unions in the Postwar Period," addressed the institutional dynamics of labor's postwar decline. A hostile legal environment helped confine unions to sectors of the economy already organized at the end of World War II. Unions did not organize outside this "core" and concentrated instead on maintaining their postwar truce with employers. This worked until the 1970s, when recession and trade shocks brought a rapid escalation in corporate assaults on labor movement strongholds and the beginnings of the catastrophic decline that ${ }^{\star}$ has continued throughout the 1980s. Rogers concluded that the unions' particularistic pursuit of self-interest made sense, given the highly centrifugal structural dynamics of the U.S. political economy. He implied, however, that had it not been for the LMRA's legal constraints the labor movement would have behaved very differently.

The conference closed with thanks to the host institutions and to the Johns Hopkins University Press for their financial support. Revised versions of the papers will be published by the Press as an essay collection.

\title{
Ninth Annual Conference, Wisconsin Labor History Society: "Reclaiming Our Local Union's History"
}

\author{
Darryl Holter \\ Wisconsin State AFL-CIO
}

One hundred labor activists, historians, and teachers gathered at the Madison Labor Temple for the Ninth Annual Wisconsin Labor History Society Conference. The topic was "Reclaiming our Local Union's History." Jeremy Brecher, author of History From Below: How to Tell the History of Your Union or Community, discussed his work with local communities and unions in several industrial areas of Connecticut.

"Building a City, Building a Movement," a video that tells the story of the Madison Federation of Labor, was introduced by Dexter Arnold, editor of Union Labor News, the monthly newspaper of the South Central Federation of Labor. Harry Miller and Jim Danky from the State Historical Society of Wisconsin discussed the historical materials available in the Society's collections. 
A panel spotlighted several local union histories. Robert Zieger, who has written a study of the Federal Labor Union at the Ray-O-Vac plant in Madison, discussed the value of working with primary historical records. Joanne Ricca described the Women in Wisconsin Labor Oral History Project. Lee Gierke explained how he and fellow unionists of the International Union of Electrical Workers Local 1131 prepared a booklet on the history of their local. Ellen LaLuzerne discussed problems in researching and writing the history of AFSCME Local 171.

Representatives from thirty unions attended the meeting. After the panel, about a dozen spoke about their plans to "reclaim" the history of their local unions. The meeting closed with election of new officers and the singing of "Solidarity Forever." 